\title{
Socio-demographic and physical-functional profile of low back pain patients assisted in Manaus-AM
}

\author{
Perfil sócio-demográfico e físico-funcional de pacientes com lombalgia atendidos em Manaus-AM
}

Jéssica Kataryna Veras dos Santos ${ }^{1}$, Vicente Fidelix Ferreira Gomes Júnior ${ }^{2}$, Andrea dos Santos Souza ${ }^{1}$, Nayana Silva Farias $^{1}$, Saulo da Silva Marques ${ }^{1}$, Joelma Magalhães da Costa ${ }^{3}$

\section{ABSTRACT}

BACKGROUND AND OBJECTIVES: Low back pain is a common pathological condition in the social environment, especially in industrialized societies, and is a frequent cause of morbidity and incapacity, being overcome only by headache in the scale of painful disorders which affect people. This study aimed at establishing the socio-demographic and physical-functional profile of patients with acute, sub-acute and chronic low back pain of specific and nonspecific origin, treated in a private physiotherapy institution of the city of Manaus/AM.

METHODS: This is a retrospective and descriptive study with quantitative approach, which has evaluated 151 medical charts, of which two were excluded for having less than 18 years of age, generating a database of 149 participants. Results were presented by descriptive statistics through central trend and variability measures, as well as by absolute and relative distribution.

RESULTS: The prevalence of low back pain was $17.3 \%$, primarily affecting males (55\%) and industrial production workers $(25.2 \%)$ with mean age of $40.7 \pm 13.2$ years. There were associated diseases in $51.6 \%(n=33)$. When submitted to palpation, $77.6 \%$ $(\mathrm{n}=85)$ have referred pain. According to body mass index calculation, $57.1 \%(n=28)$ of patients were considered overweighed; $90.0 \%(n=45)$ had abnormal postural pattern, $82.5 \%(n=80)$ had decreased lumbar spine-related movement amplitude and 55.3\% $(n=26)$ had decreased lumbar spine-related muscle strength.

CONCLUSION: Socio-demographic profile was characterized by male patients, as from the third decade of life and industrial production workers. Physical-functional profile was primarily characterized by patients with overweight and postural changes, pain at palpation and decreased lumbar region joint amplitude. Keywords: Low back pain, Patients, Private sector.

1. Centro Universitário do Norte, Manaus, AM, Brasil.

2. Curso de Fisioterapia no Instituto de Teologia Aplicada, Sobral, CE, Brasil.

3. Hospital da Força Aérea Brasileira, Manaus, AM, Brasil.

Submitted in September 11, 2015.

Accepted for publication in October 26, 2015.

Conflict of interests: none - Sponsoring sources: none.

Correspondence to:

Jéssica Kataryna Veras dos Santos

Rua Arthur Virgílio, 56 - D. Pedro II

69033-160 Manaus, AM, Brasil.

E-mail: jessicaveras_12@hotmail.com

(C) Sociedade Brasileira para o Estudo da Dor

\section{RESUMO}

JUSTIFICATIVA E OBJETIVOS: A lombalgia é uma condição patológica comum no meio social, principalmentenas sociedades industrializadas, constituindo uma frequente causa de morbidade e de incapacidade, sendo sobrepujada apenas pela cefaleia na escala dos distúrbios dolorosos que afetam as pessoas. $\mathrm{O}$ objetivo deste estudo foi traçar o perfil sócio-demográfico e físico-funcional dos pacientes portadores de lombalgia aguda, subaguda e crônica de origem específica e inespecífica, atendidos em uma instituição privada de fisioterapia na cidade de Manaus/AM.

MÉTODOS: Estudo retrospectivo e descritivo com abordagem quantitativa. Foram avaliados 151 prontuários, dos quais 2 foram excluídos por serem menores de 18 anos, gerando um banco de dados de 149 participantes. A apresentação dos resultados ocorreu pela estatística descritiva através das medidas de tendência central e de variabilidade, bem comopela distribuição absoluta e relativa.

RESULTADOS: A prevalência da lombalgia foi de 17,3\%, acometendo principalmente o gênero masculino (55\%) e trabalhadores da área de produção industrial $(25,2 \%)$ com média de idade de 40,7 $\pm 13,2$ anos. Há presença de doenças associadas em 51,6\% (n=33). Submetidos ao exame de palpação, 77,6\% $(\mathrm{n}=85)$ relataram dor. Foram classificados com sobrepeso, segundo o cálculo do índice de massa corporal $57,1 \%(\mathrm{n}=28)$ dos pacientes; $90,0 \%(n=45)$ tinham padrão postural alterado, $82,5 \%$ $(\mathrm{n}=80)$ amplitude de movimento relacionada à coluna lombar diminuída e 55,3\% (n=26) tinham força muscular relacionada à coluna lombar diminuída.

CONCLUSÃO: O perfil sócio-demográfico foi caracterizado por pacientes do gênero masculino, a partir da terceira década de vida e trabalhadores da área de produçáo industrial. $\mathrm{O}$ perfil físico funcional caracterizou-se por pacientes com sobrepeso, alteraçóes posturais, dor ao exame de palpação e amplitude articular da região lombar diminuída.

Descritores: Dor lombar, Pacientes, Setor privado.

\section{INTRODUCTION}

Low back pain is a common pathological condition in the social environment, especially in industrialized societies. According to the literature, it is estimated that approximately 70 to $85 \%$ of the world population feel or shall feel low back pain in some stage of life ${ }^{1}$. In Brazil, approximately 10 million people have incapacity associated to low back pain 
and at least $70 \%$ of the population shall have some low back pain episode along life ${ }^{2}$. Reported prevalence of low back pain in Brazil varies from 60 to $80 \%$ in total, and people aged between 50 and 59 years have the highest prevalence 3 . Low back pain is a frequent cause of morbidity and incapacity, being second only to headache in the scale of pain disorders. However, in primary care, a specific cause for low back pain and sciatic pain is found only in $15 \%$ of cases ${ }^{4}$. There are several reasons for low back pain, among them inflammatory or degenerative diseases, tumors, congenital defects, muscle weakness, and rheumatic predisposition, among others. In the approximate distribution of causes, it is observed that degenerative diseases are responsible for about $45 \%$ of the total, mechanical changes for about $25 \%$, metabolic disorders for about $10 \%$, myofascial and psychic disorders for about $10 \%$, and inflammatory diseases and visceral causes for about $4 \%$ and finally, infectious and neoplastic causes about $1 \%$ each. However, some studies try to show the association of low back pain by means of different factors, such as age, gender, smoking, alcoholism, body weight, social class, education level, practice of physical and labor activities 5 .

Low back pain diagnosis is difficult, especially due to the lack of reliable correlation between clinical and imaging findings, partially due to the complexity of the innervation of the region, except for radiculo-medullary affections, because muscle contractions, frequent and painful, are not followed by demonstrable histological injury, and due to the difficulty in interpreting painful phenomena ${ }^{6}$.

Common mechanical low back pain management is always conservative, is effective in all recovery aspects and is less expensive than surgery ${ }^{7}$, consisting in rest, local heat, antiinflammatory drugs, analgesics and neuromodulators. However, rest in the acute phase is effective but should not be prolonged due to the deleterious action of inactivity on the locomotor system ${ }^{8}$.

In light of the above, especially with regard to epidemiologic data, and taking into consideration the need for studies establishing the socio-demographic and physical-functional profile of low back pain patients in the Northern region of Brazil, especially Manaus/AM, one of the largest Brazilian industrial pole (Free Zone of Manaus - ZFM). This study aimed at establishing the socio-demographic and physicalfunctional profile of patients with acute, sub-acute and chronic low back pain, of specific and nonspecific origin, treated in a private physiotherapy institution of the city of Manaus/AM, to offer subsidies for their prevention.

\section{METHODS}

This is a retrospective and descriptive research with quantitative approach, carried out in a private physiotherapy institution in the city of Manaus/AM in 2014.

Available evaluation card records of patients of both genders meeting the following inclusion criteria were used: above 18 years of age, patients submitted to treatment of acute, sub-acute and chronic low back pain of specific and nonspecific origin, from January 2009 to June 2013. Evaluation cards not meeting any of the above-mentioned criteria were excluded.

The following variables were analyzed to establish the sociodemographic profile: gender, age and profession. To establish the physical-functional profile the following variables were analyzed: clinical diagnosis, practice of physical activity, associated diseases, major complaint, sign or symptom at palpation, body mass index (BMI), postural pattern, movement amplitude (MA) and muscle strength.

Sample size was estimated in 73 participants, considering estimated population of low back pain patients of approximately 50 to $80 \%$, according to published epidemiologic studies $^{8}$.

Initially, 151 records were evaluated, of which 2 were excluded for being below 18 years of age, generating a database with 149 patients. Records were stored in Microsoft Excel 2010 spreadsheets.

Results were presented with descriptive statistics through central trend (mean and median) and variability (standard deviation and amplitude) measures, as well as with absolute and relative distribution ( $\mathrm{n}-\%)$ with confidence interval of $95 \%$ and sample error of $5 \%(\mathrm{p}<0.05 \%)$. Age symmetry was evaluated by Kolmogorov-Smirnov test.

This study was approved by the Research Ethics Committee, Fundação de Hematologia e Hemoterapia do Amazonas HEMOAM, under opinion 566.617.

\section{RESULTS}

Initially, 151 records were evaluated, of which 2 were excluded for being below 18 years of age, generating a database with 149 patients.

The following socio-demographic results were found: predominance of males, $55.0 \%(\mathrm{n}=82)$ as compared to females, $45.0 \%(n=67)$; mean age of $40.7 \pm 13.2$ years with minimum of 18 and maximum of 76 years of age; prevailing age groups were from 30 to 39 years, $37.5 \%(n=54)$ and from 40 to 49 years, $23.6 \%(\mathrm{n}=34)$; prevalence of production-related professions. Age was absent in $3.4 \%$ of 149 evaluated records and profession was absent in $30.9 \%$. Professions distribution is shown in table 1.

Table 1. Distribution of professions of low back pain patients $(n=103)$

\begin{tabular}{lcc}
\hline Professions & $\mathrm{n}$ & $\%$ \\
\hline Domestic services & 14 & 13.6 \\
Autonomous/commerce & 6 & 5.8 \\
Administrative area & 6 & 5.8 \\
Health professional & 2 & 1.9 \\
Production area & 26 & 25.2 \\
Retired & 3 & 2.9 \\
Unemployed & 1 & 1 \\
Other & 45 & 43.7 \\
\hline
\end{tabular}


With regard to physical-functional profile, low back pain patients had the following characteristics: clinical low back pain diagnosis, $18 \%(n=25) ; 45.3 \%(n=43)$ have stated performing some physical activity; presence of associated diseases in $51.6 \%(\mathrm{n}=33)$ of cases, and most prevalent disease was hypertension, $42.4 \%(n=12)$; more than half have stated using drugs, $69.1 \%(\mathrm{n}=85)$; most recurrent primary complaint was lumbar region pain, $68.8 \%(\mathrm{n}=99)$; submitted to palpation, $77.6 \%(\mathrm{n}=85)$ have reported pain; $57.1 \%(\mathrm{n}=28)$ were classified as overweighed, according to BMI; changed postural pattern, 90.0\% ( $\mathrm{n}=45)$; movement amplitude (MA) related to shortened lumbar spine, $82.5 \%(\mathrm{n}=80)$; muscle strength related to shortened lumbar spine, 55.3\% ( $\mathrm{n}=26)$. Distribution of physical-functional profile variables is shown in table 2 .

Table 2. Physical-functional profile $(n=149)$

\begin{tabular}{|c|c|c|}
\hline Variables & $\mathrm{n}$ & $\%$ \\
\hline \multicolumn{3}{|l|}{ Clinical diagnosis - AD=16 $(10,7 \%)$} \\
\hline Tension/hypomobility & 1 & 0.8 \\
\hline Herniated disk & 19 & 14.3 \\
\hline Degenerative spondyloarthritis & 2 & 1.5 \\
\hline Low back pain & 25 & 18 \\
\hline Other & 87 & 65.4 \\
\hline \multicolumn{3}{|c|}{ Associated diseases $-\mathrm{AD}=85(57.0 \%)$} \\
\hline Diabetes (2) & 5 & 15.2 \\
\hline Hypertension (3) & 12 & 42.4 \\
\hline Cardiopathy (4) & 2 & 6.1 \\
\hline Pneumopathy (6) & 1 & 3 \\
\hline Other (8) & 19 & 57.6 \\
\hline \multicolumn{3}{|l|}{ Primary complaint $-\mathrm{AD}=7$ (4.6\%) } \\
\hline Neck pain & 9 & 6.3 \\
\hline Chest pain & 4 & 2.8 \\
\hline Back pain & 99 & 68.8 \\
\hline Back pain irradiated to LLLL & 31 & 21.5 \\
\hline Paresthesia & 1 & 0.7 \\
\hline Other & 6 & 4.2 \\
\hline \multicolumn{3}{|l|}{ Palpation - AD=40 (26.8\%) } \\
\hline Pain at palpation & 85 & 77.6 \\
\hline Tension & 6 & 5.5 \\
\hline Trigger-points & 1 & 0.9 \\
\hline No pain at palpation & 17 & 15.5 \\
\hline \multicolumn{3}{|l|}{$\mathrm{BMI}-\mathrm{AD}=101(66.9 \%)$} \\
\hline Low weight & 0 & 0 \\
\hline Normal weight & 13 & 26.5 \\
\hline Overweight & 28 & 57.1 \\
\hline Obese & 8 & 16.3 \\
\hline \multicolumn{3}{|l|}{ Postural pattern - AD=99 (66.4\%) } \\
\hline Unchanged & 5 & 10 \\
\hline Changed & 45 & 90 \\
\hline \multicolumn{3}{|l|}{$M A-A D=52(34.9 \%)$} \\
\hline Unchanged & 17 & 17.5 \\
\hline Limited & 80 & 82.5 \\
\hline \multicolumn{3}{|l|}{ Muscle strength - AD=102 (68.5\%) } \\
\hline Unchanged & 21 & 44.7 \\
\hline Decreased & 26 & 55.3 \\
\hline
\end{tabular}

$\mathrm{AD}=$ Number of absent data in the evaluation record; LLLL = lower limbs; BMI = body mass index; $\mathrm{MA}=$ movement amplitude.

\section{DISCUSSION}

Among records evaluated in this study, $17.3 \%$ had low back pain, which is different from most studies. Authors have observed $40 \%$ of individuals with low back pain from a total of 80 , in a study aiming at finding possible relationships between low back pain and lumbar-pelvic motor control deficit in jiu-jitsu fighters ${ }^{10}$. Another study ${ }^{11}$, evaluating prevalence of spinal pain and associated factors in 972 adults from the city of Pelotas RS, has observed prevalence of $40 \%$ of low back pain. A different research ${ }^{12}$ evaluating with a questionnaire 115 people among employees, students and professors of the Centro Universitário UNIEURO, has found higher scores, with prevalence of $46 \%$; however, data comparisons should be seen with care, since the study is with a sample of specific workers, who do not represent general population.

Epidemiologic data from other countries show higher low back pain prevalence than that observed in Brazil. This difference may be explained by the lack of methodological rigor and of standardization of criteria adopted for pain classification in some Brazilian studies ${ }^{13}$. Also, in our study, diagnostic was retrospective and in medical records, which might have also influenced results.

With regard to gender, there has been higher prevalence of low back pain among males, corresponding to 82 individuals (55\%), while females were 67 (45\%), confirming Abreu \& Ribeiro ${ }^{14}$ data who studied a population inserted in the Social Security Professional Rehabilitation Program of the city of São Luís/MA, having analyzed 88 medical records of people in medical leave, where 83 (94.3\%) were males. However, our study is different from results found by Antunes et al. ${ }^{15}$ which show female prevalence, $140(72.5 \%)$, as compared to males, $53(27.5 \%)$. The mean age was $40.7 \pm 13.2$ years, and observed age of 18 and maximum of 76 years. Similar result was found by Abreu $\&$ Ribeiro ${ }^{14}$ who have obtained mean age of 41 years and by Martins ${ }^{16}$, who has identified a high prevalence of low back pain in 41 years old individuals.

According to Almeida et al. ${ }^{13}$, low back pain is a common pathological condition in the social environment, especially in industrialized societies, which may explain its prevalence in males in our study, considering that Manaus/AM is one of the largest Brazilian industrial poles and most workers from this sector are males.

According to Khouri et al. ${ }^{17}$, prevalence increases with age, affecting a larger number of individuals during the sixth decade of life, and affecting approximately $80 \%$ of the world population. Braga et al. ${ }^{18}$ have reported that low back pain affects the economically active population causing major impact on their health, thus being a reason for absenteeism.

Among observed professions, production had the highest prevalence, which is different from the study by Hoffman ${ }^{19}$ who, in evaluating the prevalence of back pain in elderly patients submitted to physiotherapy in a clinic in the city of Concórdia/SC, has observed prevalence of pain both in females and males, in agriculture and general services workers. According to a descriptive research ${ }^{20}$ in a production sector of 
a Food Industry in the city of Marília/SP, limited to a specific sector where 30 male workers were interviewed, 14 workers $(46.6 \%)$ have referred some musculoskeletal symptom in some spinal segment, prevailing low back pain (33.3\%). Authors state that musculoskeletal symptoms in spinal segments are closely related to postures and movements adopted at work, such as trunk bending, trunk torsion, and picking, putting and dragging heavy material.

Pain at lumbar palpation was present in $77.6 \%$ of evaluated records. A study carried out in three health centers and one private hospital from Campinas, with 34 nulliparous pregnant women divided in two groups (one with 17 pregnant women submitted to Global Postural Reeducation (RPG) and the other group following routine guidance for low back pain control, with gestational age between 20 and 25 weeks and low back pain complaint, has found that 10 women from the RPG group and seven from the control group had pain at lumbar muscles palpation ${ }^{21}$. In a study by Ramírez \& Lemus $^{22}$, with 67 students of the second year of a physiotherapy course, from March to August 2010, 6.3\% of students have referred pain at lumbar palpation.

It is possible to state that low back pain is directly related to muscle strength loss, because according to Conceição \& Karolczak $^{23}$, people with low back pain in general have muscle unbalance, such as weakness or shortening, characterized by intra-articular regions of hypomobility and hypermobility.

Among evaluated records, $90 \%$ showed postural pattern changes. In a study by Signoret $\&$ Parolina ${ }^{24}, 16$ adult male "capoeira" players from the city of São Paulo had spinal changes and approximately 56\% had lumbar hyperlordosis. In a study with 288 students of the Federal Teaching Network of Florianópolis (156 males and 132 females), aged between 15 and 18 years, the prevalence of sagital postural deviations in the lumbar spine was high, reaching $53.8 \%$ of evaluated students ${ }^{25}$.

According to Rumaquella \& Santos Filho ${ }^{20}$, remaining in the standing position for long periods generates lumbar muscles fatigue, associated to trunk torsion and flexion movements and load transportation, which contributes for more frequent low back pain and may cause several spinal problems. This confirms our results, where most people affected by low back pain were industry workers who have as typical activities remaining for long periods in the same position, such as: carry load, make trunk rotational movements and many repetitive movements, being this, probably the major reason for postural pattern changes.

\section{CONCLUSION}

Socio-demographic profile was characterized by male patients, as from the third decade of life and workers of industrial production area.

Physical-functional profile was characterized by patients with overweight, postural changes, pain at palpation and decreased joint amplitude in lumbar region.

As proposal for future studies, it is suggested that, in addition to aspects evaluated in this study, other variables involved in low back pain process, such as pain at palpation, postural pattern, MA and muscle strength, are investigated in further details.

\section{REFERENCES}

1. Macedo CS, Briganó JU. Terapia manual e cinesioterapia na dor, incapacidade e quali dade de vida de indivíduos com lombalgia. Espaç Saúde. 2009;10(2):1-6.

2. Oliveira VC, Furiati T, Sakamoto A, Ferreira P, Ferreira M, Maher C. Health locus of control questionnaire for patients with chronic low back pain: psychometric properties of the Brazilian-Portuguese version. Physiother Res Int. 2008;13(1):42-52.

3. Bhangle SD, Sapru S, Panush RS. Back pain made simple: an approach based on principles and evidence. Clev Clin J Med. 2009;76(7):393-9.

4. Lopes TM, Casa Júnior AJ. Avaliação da capacidade funcional e da qualidade de vida de indivíduos com dor lombar inespecífica. Estudos. 2014;41(2):223-35.

5. Barbosa MH, Silveira TB, Lemos RC, Zuffi FB. Lombalgia: fatores de melhora e piora entre os clientes atendidos no ambulatório de ortopedia. Saúde Coletiva. 2011;47(8):18-23

6. Manusov EG. Low back pain diagnosis and treatment. Preface. Prim Care 2012;39(3):xi-xii.

7. Anandani G, Shetty GM, Bafna S, Narula N, Gandhi A. Effectiveness of devicebased therapy for conservative management of low back pain. J PhysTher Sci. 2015;27(7):2139-41.

8. Helfenstein Junior M, Goldenfum MA, Siena C. [Occpationallowbackpain]. Rev Assoc Med Bras. 2010;56(5):583-9.English, Portuguese.

9. Busse JW, Ebrahim S, Heels-Ansdell D, Wang L, Couban R, Walter SD. Association of worker characteristics and early reimbursement for physical therapy, chiropractic and opioid prescriptions with workers' compensation claim duration, for cases of acute low back pain: an observational cohort study. BMJ Open. 2015;5(8):e007836.

10. Costa JE, Lima DV, Frigo L. Avaliaçáo da dor lombar e do controle motor da regiấo lombopélvica em lutadores de Jiu-Jitsu. Rev Publ UEPG Ci Biol Saúde. 2013;19(2):103-13.

11. Ferreira GD, Silva MC, Rombaldi AJ, Wrege ED, Siqueira FV, Hallal PC. Prevalência de dor nas costas e fatores associados em adultos do Sul do Brasil estudo de base populacional. Rev Bras Fisioter. 2011;15(1):31-6.

12. Domínguez AG. Prevalência de Lombalgia em acadêmicos e funcionários do Centro Universitário UNIEURO. Rev Habilitar. 2008;1(2):63-8.

13. Almeida IC, Sá KN, Silva M, Baptista A, Matos MA, Lessa I. Prevalência de dor lom bar crônica na população da cidade Salvador. Rev Bras Ortop. 2008;43(3):96-102.

14. Abreu AT, Ribeiro CA. Prevalência de lombalgia em trabalhadores submetidos ao programa de Reabilitação Profissional do Instituto Nacional do Seguro Social (INSS). Rev Acta Fisiátr. 2010;4(17):48-52.

15. Antunes RS, Macedo BG, Amaral TS, Gomes HA, Pereira LS, Rocha FL. Dor, cinesiofobia e qualidade de Vida em pacientes com lombalgia crônica e depressão. Rev Acta Ortop Bras. 2011;21(1): 27-9.

16. Martins MR. A eficácia da consulta do grupo de postura em pacientes com lombalgia crônica. Rev Dor. 2010;11(2):116-21.

17. Khouri ME, Cobertt CE Cordeiro Q, Ota D. Prevalência de lombalgia em garimpeiros de Serra Pelada, Pará/Brasil. Rev Acta Fisiátr. 2008;15(2):82-6.

18. Braga AB, Rodrigues AC, Lima GV, Melo LR, Carvalho AR, Bertolini GR. Comparaçâo do equilíbrio postural estático entre sujeitos saudáveis e lombálgicos. Rev Acta Ortop Bras. 2012;20(4):210-2.

19. Hoffmann M. A prevalência de doenças lombares em pacientes de terceira idade na cidade de Concórdia - SC. Ágora. 2010;17(1):62-70.

20. Rumaquella MR, Santos Filho AG. Postura de trabalho relacionada com as dores na coluna vertebral em trabalhadores de uma indústria de alimentos: estudo de caso. Rev Educ Gráf. 2010;14(1):90-101.

21. Gil VF, Osis MJ, Faúndes A. Lombalgia durante a gestaçâo: eficácia do tratamento com Reeducação Postural Global (RPG). Fisioter Pesqui. 2011;18(2):164-70.

22. Ramírez CR, Lemus DM. Disfunçâo da articulação sacro-ilíaca em jovens com dor lombar. Rev Fisioter Mov. 2010;23(3):419-28.

23. Conceiçâo LB, Karolczak AP. Análise neuromuscular dos músculos estabilizadores do tronco em indivíduos com e sem lombalgia. Rev Ter Man. 2010;8(39):389-95.

24. Signoreti MM, Parolina EC. Análise postural em capoeiristas da cidade de São Paulo. Aspectos fisiológicos e biomecânicos. Rev Fac Ciên Saúde. 2009;6(2009):462-70.

25. Graup S, Santos SG, Moro AR. Estudo descritivo de alteraçôes posturais sagitais da coluna lombar em escolares da Rede Federal de Ensino de Florianópolis. Rev Bras Ortop. 2010;45(5):453-9. 